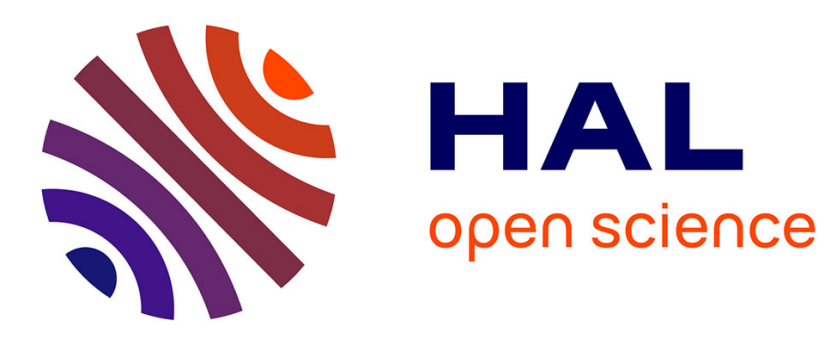

\title{
Liberalization in the Water Sector: Three Leading Models.
}

Claude Ménard, Peeroo Aleksandra

\section{To cite this version:}

Claude Ménard, Peeroo Aleksandra. Liberalization in the Water Sector : Three Leading Models.. Rolf Kunneke and Matthias Finger. International Handbook of Network Industries: The Liberalization of Infrastrcutures, Edward Elgar, pp.310-327, 2011. halshs-00624303

\section{HAL Id: halshs-00624303 \\ https://shs.hal.science/halshs-00624303}

Submitted on 20 Sep 2011

HAL is a multi-disciplinary open access archive for the deposit and dissemination of scientific research documents, whether they are published or not. The documents may come from teaching and research institutions in France or abroad, or from public or private research centers.
L'archive ouverte pluridisciplinaire HAL, est destinée au dépôt et à la diffusion de documents scientifiques de niveau recherche, publiés ou non, émanant des établissements d'enseignement et de recherche français ou étrangers, des laboratoires publics ou privés. 


\title{
Liberalization in the Water Sector: Three leading models.
}

\author{
Claude Ménard \& Aleksandra Peeroo \\ Centre d'Economie de la Sorbonne (CES) \\ University of Paris (Pantheon-Sorbonne)
}

\author{
Paper published in: \\ Finger, Matthias and Rolf Kunneke (eds.) \\ Handbook of Liberalization. E.Elgar Pub. (2011) \\ Chap. 18, pp. 310-327
}




\title{
Liberalization in the Water Sector: \\ Three leading models.
}

\author{
Claude Ménard \& Aleksandra Peeroo
}

\section{INTRODUCTION.}

Over the last 15 to 20 years, problems in the water sector have become more visible and pronounced. Developed countries struggle to provide the much needed investments to maintain and update their water systems. The main concern in less developed countries on the other side is the lack of access to safe drinking water which combined with inadequate sanitation causes more than five million deaths every year ${ }^{2}$. Being aware of these difficulties and the pervasive changes in other infrastructure sectors, one must note the remarkably slow pace of reform in the water sector. Moreover, the most systematic reforms until now have been implemented in developed countries although the situation of the water sector seems less urgent than in the developing world ${ }^{3}$.

By reform, we mean substantial changes in decision rights, changes that modify the governance and in many cases the allocation of property rights of the existing operator. Thus understood, reform can take many different forms. Since the early 1980s, its epitomized model has been that of liberalization, identified to the introduction of competition and, most of the time, to privatization. However, it might be relevant to retain a broader definition of liberalization, particularly in the water sector, in which competition in the market barely exists while competition for the market remains a challenge. In this chapter we consider liberalization in the continuation of Baumol, Panzar \& Willig (1982), as reforms that introduce contestable markets. Beside full privatization, private sector participation in its different forms is therefore part of that movement. It can even be argued that corporatization, and the

\footnotetext{
${ }^{1}$ Both at the Centre d'Economie de la Sorbonne (CES), Université de Paris (Panthéon-Sorbonne).

${ }^{2}$ The literature on water issues is much more substantial than what is available on sanitation, although epidemiologists have shown that safe water without adequate sanitation does not do the job (Esrey, 1996).

${ }^{3}$ This is beginning to change however: on the one hand, reforms become more far-reaching in less developed countries and on the other hand, the provision of drinkable water becomes a more critical issue in high income countries, its specter already showing up in the Southern belt of the European Union for instance.
} 
market pressure it intends to introduce on public entities, is a step in that direction since it makes public corporations more responsible and more responsive to incentives ${ }^{4}$.

This extended concept of liberalization might be useful to capture what has been and is still going on in the water sector. Indeed, full privatization remains an exception in the sector. In Western Europe, notwithstanding the isolated case of England and Wales, liberalization has mainly taken the form of private sector participation ${ }^{5}$. Correspondingly for less developed countries, Gassner, Popov \& Pushak (2009) show in their extensive survey of reforms of urban water and sanitation systems that State Owned Enterprises (SOE) ${ }^{6}$ still represent the standard case. Only 141 reforms translated into significant changes in ownership of the entities involved, under the form of private sector participation, of which only 10 percent is divestiture (ibid. p. 24), with these changes mostly concentrated in Latin America and the Caribbean (Gassner, Popov \& Pushak 2007, p. 29) ${ }^{7}$.

The mixed results achieved by the reform movement make things even more complex. Indeed, although the literature on the issue is still very limited, data available show ambiguous outcomes when comparing the performance of reformed SOE to solutions involving private sector participation; and similarly there is no straightforward answer when comparing the performance of the various forms of private participation (Ménard \& Saussier, 2002; Gassner et al., 2009; Wallsten \& Kosec, 2008) ${ }^{8}$.

In what follows, we focus on organizational alternatives involved in liberalization processes as defined above, in order to emphasize the challenging institutional changes at stake and the various difficulties these solutions face. Since most changes have occurred in urban water systems so far, we leave aside the

\footnotetext{
${ }^{4}$ The public debate about corporatization is ambiguous, with some viewing corporatization as a step towards full privatization while others consider it is a cover for public entities to escape liberalization.

5 According to Pinsent Masons (2008), it represents $40 \%$ of the provision of water in this area. However, this might be an exception for the time being. In the US, reforming the water sector remains very low on the agenda of policy makers. Even in Europe, despite pervasive private sector participation in some countries, the liberalization of the water sector keeps being limited in scope and scale, as well illustrated in Finger, Allouche \& Luis-Manso, 2007.

${ }^{6}$ By State Owned Enterprises (SOE), we mean all entities owned and monitored by public authorities, central, regional, or local.

${ }^{7}$ However, trends toward private sector participation seem to have developed in Asia over the last years. See http://ppi.worldbank.org/explore/ppi exploreSector.aspx?SectorID=2 (accessed 7 April 2011)

${ }^{8}$ For recent and challenging views about the successes of private sector participation, see World Bank (2009) and Cave (2009).
} 
problems of liberalization in the provision of water and irrigation in rural regions, and the difficult trade-offs it involves.

Our chapter is organized as follows. Section I comes back to the characteristics of the water sector. It describes some key features that may explain the slow pace of reform and that may also help better understanding characteristics and limits of that process. Then, a historical and global overview of the liberalization movement and the actual state of the water sector is presented. Section II examines more specifically the main drivers towards and factors of resistance to the liberalization process in the water sector. Section III looks at how these factors operate in three models of liberalization, illustrated with as many stylized examples from European countries $^{9}$. Section IV takes stock of this examination to point out challenges of liberalization in the water sector, which have to do with guaranteeing integrity and coherence of water systems. The conclusion then summarizes our main arguments and raises some important issues not discussed in the chapter.

\section{SECTION I: CHARACTERISTICS OF THE WATER SECTOR.}

In order to understand the difficulties faced by reforms of urban water systems and the very limited steps towards liberalization, even in countries that championed this type of reform, we have to keep in mind some key characteristics of water systems.

\section{I.1: Inherent attributes in comparison with other infrastructures.}

On the one hand, water systems share common features with other "critical infrastructures" that have been liberalized ${ }^{10}$. It is a network industry that looks like the epitome of a natural monopoly. Urban water systems benefit from substantial economies of scale and recent technological developments facilitating the installation of insulated cables within water networks allow economies of scope.

\footnotetext{
9 There are several reasons why we focus on these examples. First, the examples provide a relatively wide spectrum of alternative solutions for liberalization. Second, the institutions, the level of development of these countries and the characteristics of their water systems make comparisons meaningful and allow the argument to focus on the main issues at stake. Last, but not least, complex matters in developing countries could hardly be encompassed in the limits here.

${ }^{10}$ By critical infrastructures, we mean infrastructures that are fundamental for the functioning of our societies, so that they must be reliable, safe, and secured (Kunneke, Groenewegen \& Ménard, 2009).
} 
On the other hand, there are substantial differences with other network industries, such as electricity or gas, not to mention telecommunications, which make urban water systems less prone to liberalization. First, the proportion of sunk costs in urban water systems has no parallel in other sectors. Second, urban water systems benefit from very substantial economies of density, so that competing entities would have little incentives to extend the network to areas with small and dispersed population. Third, because of the high costs of long distance transportation, urban water systems are decentralized. Fourth, the implementation and maintenance of water systems involve important externalities: they can disrupt economic activities, as when repairs disturb urban traffic; they can benefit from urban planning; and they can have an immediate impact on health. Fifth, water has no substitute and concerns all human beings, with no exception. As such, it is perceived as a "social" good that imposes strict constraints on operators, whether they are public or private, particularly when it comes to pricing and operation. Last, because there is no substitute, competing usages are a continuous and increasing source of tension.

As a consequence, urban water systems combine two sets of difficulties that hamper "liberalization". First, the need to maintain the technical integrity of these systems under the conditions described above imposes a mode of organization that locally remains almost everywhere a 'natural monopoly'. Second, because these monopolistic properties combine with a 'good' absolutely essential to human survival, water systems require institutions that guarantee the coherence between technicalorganizational requirements and needs to be satisfied: this could well explain why water systems remain so tightly regulated, whatever the type of reforms implemented $^{11}$.

\section{I.2: Organization of the water sector.}

Indeed, the slow pace of reform in the water sector contrasts with the substantial changes that have affected other network industries. The push towards liberalization in the network industries was initiated in the developed countries and rapidly took the form of deregulation. It started in the airline industry in the United States, with the deregulation process of the late 1970s. The telecommunication sector in the US followed shortly after. This movement accelerated throughout the

\footnotetext{
${ }^{11}$ For a more detailed analysis of these two set of difficulties, see Ménard (2009).
} 
1980s with other countries endorsing similar reforms, first with telecommunications, then with energy, urban and rail transportation and, later on, water. What was acknowledged to work in the developed countries was then exported towards the developing world, particularly at the initiative and under the pressure of the World Bank in conformity with the so-called "Washington Consensus"12.

Liberalization then became identified with privatization. However, the two concepts differ. Strictly speaking, privatization involves the transfer of property rights on assets from public to private entities. Liberalization refers to a broader and in a sense less specific policy, which is to introduce competitive pressure, without necessarily involving privatization. Whereas full privatization is often viewed as a way to reform infrastructures, with telecommunications as the paramount example, energy or more recently railways, it was and remains a very uncommon solution in the water sector due to its specificities, England \& Wales being the main and most significant exception. However, rules designed to introduce competitive pressure have been adopted in many countries.

This trend towards liberalization in network industries has been accompanied by substantial changes in the mode of regulation. The organization of the market is increasingly switching from a "command-and-control" to a contractual approach. In network industries, deregulation rarely meant full competition. It rather focused on introducing "competition for the market" wherever implementation of "competition in the market" was not possible or too costly, and often did so through contracts. "Corporatization" of public entities, "Private Sector Participation", "Public-Private Partnership," became various tools in the hands of market-oriented reformers. Over the last 20 years the number of people worldwide provided with drinking water by the private sector rose to 753 million $^{13}$ (Pinsent Masons 2008, p. 30). The actual situation and its recent evolution for the different regions in the world are summarized in table 1.

\footnotetext{
12 This program is explicit in World Bank (1994). For a summary and discussion of the "Washington Consensus", see http://en.wikipedia.org/wiki/Washington_Consensus. (accessed 7 April 2011)

${ }^{13}$ This number being an estimate (the same author proposes 721 million, p. 40).
} 
Table 1: Number of persons served by the private sector per region

\begin{tabular}{|l|r|r|}
\hline \multirow{2}{*}{ Region } & \multicolumn{2}{|c|}{$\%$ people } \\
\cline { 2 - 3 } & 2004 & 2008 \\
\hline Western Europe & $45 \%$ & $44 \%$ \\
\hline C \& E Europe & $5 \%$ & $10 \%$ \\
\hline ME \& Africa & $4 \%$ & $6 \%$ \\
\hline South \& Central Asia & $0 \%$ & $1 \%$ \\
\hline South East Asia & $6 \%$ & $12 \%$ \\
\hline Oceania & $10 \%$ & $25 \%$ \\
\hline North America & $19 \%$ & $21 \%$ \\
\hline Latin America & $21 \%$ & $17 \%$ \\
\hline World total & $\mathbf{9} \%$ & $\mathbf{1 1} \%$ \\
\hline
\end{tabular}

Source: Adapted from Pinsent Masons (2004, p. 19 and 2008, p.40).

Although the exactitude of such aggregated data remains always debatable, the magnitude is unambiguous: only about one tenth of the world's population receives its drinking water from a private entity, often under the form of partnerships in which private operators have a rather limited role. Public management is the prevailing mode of organizing the water sector, with an overwhelming majority of $89 \%$. Keeping the perception of water as a social good in mind, this result might not be that surprising. The United States and Canada, but also some European countries like the Netherlands and Germany, most of the Middle Eastern countries (e.g. Egypt, Iran, and Lebanon), all South Asian states and most of Africa are examples for this type of water service provision. However, public management takes many different forms. There are major differences between direct public management, in which the provision of water services depends on the general municipal budget or an independent department of the local administration, and delegated public management, in which the municipality "delegates" the provision to a communal enterprise which operates under company law. The switching from direct to delegated public management during a reform process is known as corporatization, and can be viewed as a step towards liberalization ${ }^{14}$.

\footnotetext{
${ }^{14}$ However, as already mentioned, it could also be viewed as a way to avoid privatization and real competition.
} 
A second interesting finding, as shown by table 1, concerns the geographic concentration of private sector participation in the provision of water. Indeed, substantial private involvement exists primarily in Western Europe (and mainly in the United Kingdom and France, to a much lesser extent in Spain, Greece, and Italy), which confirms that so far most reforms involving the private sector have been implemented in developed countries. Table 1 also shows the state of private sector participation in Latin America, for the most part in Chile, but also in Columbia and Brazil $^{15}$.

However, these numbers can be misleading insofar as providing an umbrella to many different forms of private participation. Full privatization, with the sale of the physical assets (pipes etc.) and therefore the transfer of the main property and decision rights to a private owner, is a mode of organizing the provision of drinking water that has found nation-wide application only in England \& Wales and is otherwise merely very sporadically used (for instance in the Czech Republic or in Chile). The concept of Public-Private Partnerships (PPPs) in turn is much broader, including a variety of solutions, which depend on the distribution of decision rights between the public and the private party. At one end of the spectrum of PPPs, commercial service contracts call the private entity to provide specific services on behalf of the municipality, such as billing or collecting invoices. Management and lease contracts attribute further responsibilities to the private operator, e.g. the operation and maintenance of the water system. This form of PPP is often used when the necessary infrastructure already exists. Concessions are at the other end of the spectrum: the private partner has not only to operate and maintain the system, but also to provide the necessary investments. Figure 1 summarizes the main arrangements in the provision of water as classified by the degree of control over decision and property rights and the key variables at stake.

Figure 1: Different arrangements for providing water

(or other public utilities in that respect)

\footnotetext{
${ }^{15}$ Recent data suggest important breakthrough of private sector participation in Asia (http://ppi.worldbank.org/explore/ppi exploreRegion.aspx?regionID=2) (accessed 7 April 2011)
} 


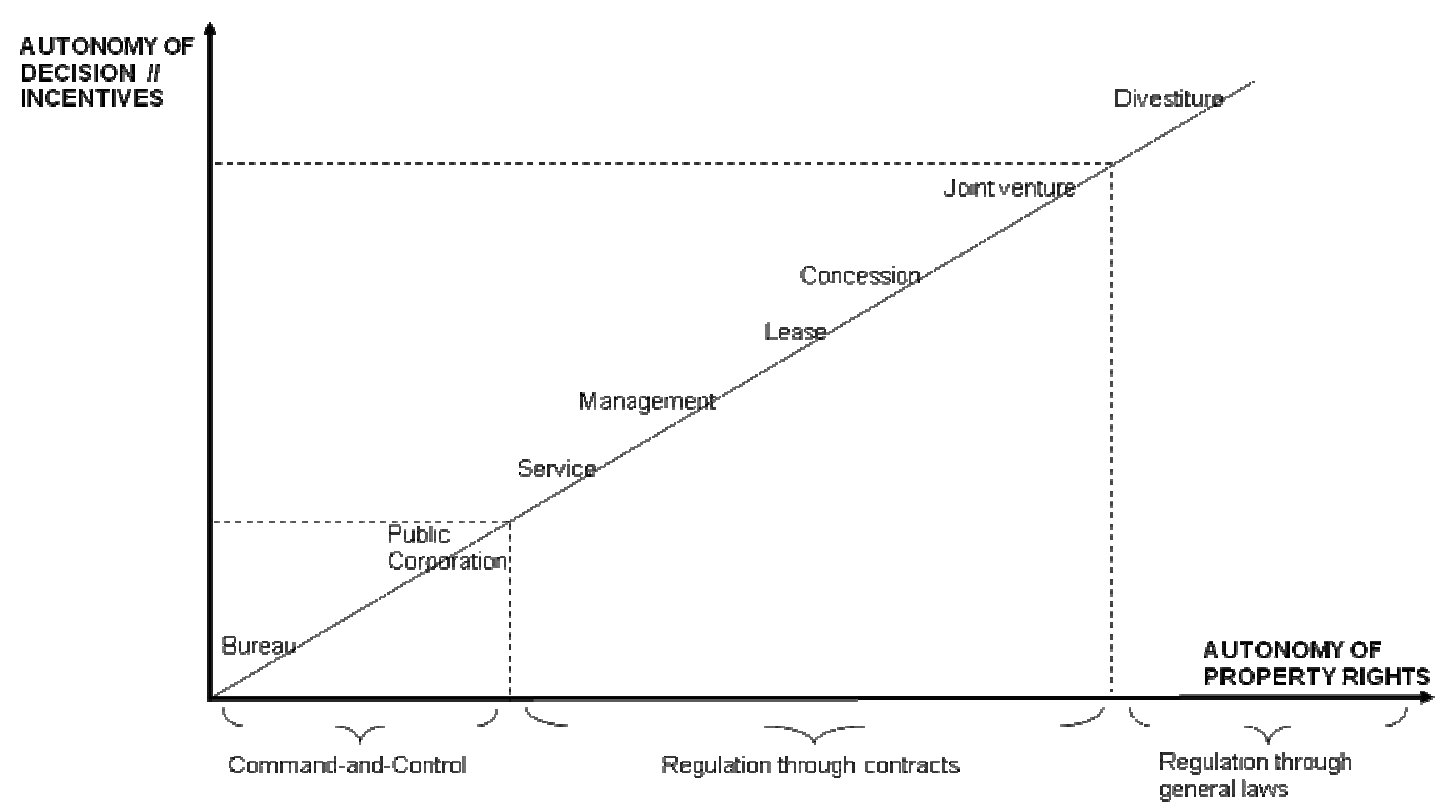

Source: Adapted from Ménard, 2009, p.97

\section{SECTION II: DRIVERS AND CHALLENGES TOWARDS LIBERALIZATION IN THE WATER SECTOR.}

The movement towards liberalization of urban water systems was mainly driven by financial and ideological factors. Yet, it turned out to be far less "liberal" than in other sectors.

\section{II.1: The main drivers towards reform.}

The most important driver towards water sector reform has been and remains finance (Finger et al., 2007, p. 3). While developing countries face the huge costs of expanding systems for an explosive urban population, public entities in developed countries have to deal with ageing networks that need heavy investments. Even in well maintained systems, municipalities have to face investments required by tougher quality standards and new legislative frameworks. According to Hall and Lobina (2007) the urban wastewater directive of 1991 (91/271/EEC) provides one illustration of a regulation having a major impact by significantly increasing the costs of water services. In order to implement the standards required and to avoid increased taxes or responsibilities for higher prices of water, municipalities have a strong incentive to 
delegate the provision of water services to private partners, or to corporatize public entities in the hope of realizing efficiency gains ${ }^{16}$.

The inclination to do so has been amplified by the increasing technical complexity of water systems, largely due to the implementation of stringent quality standards (Massarutto, Linares \& Paccagnan, 2007, p. 198). Even in developed countries, municipalities or regional authorities often lack the necessary expertise while private water companies have acquired technical know-how during long years of business. This may also help to understand why a handful of big companies dominate this market.

Moreover, the massive investments required, either because of higher quality standards, or because of the need to renovate ageing systems, or because of the demographic explosion in developing cities, are confronted everywhere with major budget constraints. For example, in the case of the European Union, the so-called "stability pact" of 1992 imposed tougher rules on the budget of the member states, with a cascading effect even when water services fell under the responsibility of municipalities, since subsidies and/or financial support were increasingly restricted (Schouten \& van Dijk, 2007, p. 30). Similarly, in developing countries, pressures towards liberalization and private sector participation took place in contexts in which the water sector crisis combined with major macroeconomic constraints (Shirley \& Ménard, 2002).

These factors provided support to the belief that became dominant in the 1990s that liberalization would solve these problems at a lower cost than if water remained in the hands of public authorities. One must keep in mind that "liberalization paired with privatization" was the great slogan of the so-called "Washington Consensus," with the hope that process would feed growth.

\section{II.2. Meeting resistance.}

However, for reasons partially embedded in the specific characteristics of the water sector (see Section I), coalitions of interests - including users - tend to develop resistance to that process almost everywhere. One reason might be that users are unwilling to see the provision of a good essential to their survival and without substitute in the hands of private monopolies. Most interestingly, this

\footnotetext{
${ }^{16}$ See Garcia , Guérin-Schneider \& Breuil (2007), p. 57 f.
} 
resistance seems to be less rooted in the fear of higher tariffs - although this might become an issue when pricing rules are perceived as unfair (Shirley \& Ménard, 2002) - than in the perception that water is a critical infrastructure providing an essential public good that should remain within public hands or, at least, under extremely tight public control. A review of recent surveys clearly exhibits this trend when it comes to water (Bonnet, Dubois, Martimort \& Straub, 2006).

Of course this resistance is fed by rent seeking groups. With liberalization identified to privatization or significant private participation and with the perspective that "rationalization" will follow with major job cuts, unions tend to oppose these plans in order to maintain employment for their members. In several cases, such resistance led to changes in the initial plans. For example, in Munich unions successfully prevented the corporatization of sanitation services (Lanz, 2005). In some cases, public authorities and/or international donors have tried to anticipate these problems, accompanying reforms with sweet pills for employees (Shirley, 2002; Pérard, 2007).

One last obstacle to liberalization comes from government opportunism (Savedoff \& Spiller, 1999, chapter 1). This problem is rooted in the different length of the life cycles of a politician and a public utility, particularly of water systems where water pipes can reach roughly 80 years if properly maintained. As a result, public officials do not feel too committed to the long-term effects on the network of the solutions they adopt. In the long run, providers of water services need to recover the high costs of their sunken assets, but in the short run they can survive with prices that cover only operating costs, which are well under average costs. This provides strong incentives for government opportunism - keeping prices low for electoral purposes. Consequently, private sector participation might be discouraged, particularly if public commitments are not credible, which depends on institutional endowments, notably political institutions. Note that political risks might also hamper public corporations, challenging reforms even when there is no change in formal ownership.

\section{SECTION III: THREE MODELS EXAMPLIFIED BY EUROPEAN CASES.}

The distinct forms that liberalization can take in the water sector and the problems they face are well illustrated by the recent evolution of several European 
countries. As suggested above, the need to guarantee the technical integrity of water systems and the coherence between a system and the needs it must meet could well explain resistance to radical changes, the fact that liberalization has secured local integrated monopolies everywhere and that it happened with a rather slow pace.

In order to substantiate our argument, we focus on the urban water sector in three countries: England \& Wales, France, and Germany. In our view, they offer three alternative models of liberalization in the water sector: England \& Wales have privatized their water sector as early as 1989 ; France, which has a long tradition of PPP in that sector, has introduced significant changes to increase competitive pressure; and Germany has basically maintained the public management of its system, although with a trend towards corporatization. In what follows we emphasize structural characteristics typifying each form, but we also exhibit commonalities that, in our view, come from the need to align the modes of organization to socio-technical requirements of urban water systems.

\section{III.1: England \& Wales: Full privatization, but close monitoring ${ }^{17}$.}

The example of England \& Wales is unique in that no other country has completely privatized its water sector. This case provides a stylized example of how financial considerations backed by a strong ideology fed the most radical form of liberalization: full divestiture.

However, this "natural experiment" has at least two distinguishing features with respect to reform of other utilities. First, because of the characteristics of water systems emphasized above, the sector remains tightly monitored through the very visible hand of an independent regulator, the Water Services Regulation Authority (OFWAT). Second, and this makes the case even more interesting, while liberalization of the water sector in most countries goes hand in hand with a decentralization process, it went the opposite direction in England \& Wales, having been accompanied by an increased centralization. As early as 1973, municipalities started losing their grip over water services, with the creation of 10 Regional Water Authorities based on river basins. These authorities were not only responsible for water resource management but also for the provision of water and sanitation services.

\footnotetext{
${ }^{17}$ For a relatively detailed overview of the UK water sector, see Euromarket 2004a: Case study UK.
} 
In 1989, these Regional Water Authorities were privatized and their original tasks split. Water resource management fell into the hands of the newly created National River Authorities, a public entity that was replaced by the Environmental Agency in the mid-90s. The newly created water companies on the other hand were legally bound to provide water and sanitation services. They hold both property and decision rights, and assume all the risks of a private company. At the same time, they operate under severe constraints imposed by several national regulators. Therefore, liberalization operates under a quite complex institutional arrangement.

Of particular interest for our purpose is the role of OFWAT, which is to promote competition and to protect consumer interests. Users actively participate in the regulation process through the 10 Consumer Councils for Water. These Consumer Councils are in direct contact with both the water companies and with OFWAT. By dealing with consumer complaints, the Councils play an important role in supporting OFWAT's monitoring of the private water companies. Furthermore, the Consumer Councils for Water and OFWAT are legally bound, via the Water Act of 2003, to cooperate and exchange information. This can be of particular importance when major decisions like a merger of water companies are debated. OFWAT operates as a classical regulator, not that different from the traditional regulatory commissions of public utilities, setting performance standards and service targets and, above all, fixing tariffs. The innovation is that OFWAT uses a price cap mechanism that, in principle, is reviewed every five years and automatically takes into account inflation, performance, and efficiency. Through benchmarking, OFWAT is also in charge of ensuring (virtual) competition.

However, the five years term was not fully respected. Due to a rapid increase in prices paralleled with jumps in profits of operators that generated a public outcry, the regulator intervened and changed the rules of the game ${ }^{18}$. Moreover, there is a continuing debate on the effectiveness of a solution with almost no competition in the market. Therefore, next to the already existing yardstick competition which is a major tool in the hands of the regulator, new instruments have been introduced or are under consideration (Euromarket, 2004a, p. 341f; Cave, 2009). One way is the socalled common carriage which consists in the sharing of one operator's physical

\footnotetext{
${ }^{18}$ With the Water Act of 2003, OFWAT's mission officially switched from facilitating to effectively promoting competition. Since then, OFWAT's price caps have become tighter, squeezing the profits of the private water companies.
} 
assets (pipes...). Another approach is to enhance competition on the vertical supply markets meaning that the water companies delegate intermediate activities to other party(ies). Furthermore, the introduction of cross-border supplies is meant to allow consumers to get a connection from another supplier. There are also self-contained water supplies, with privately-owned wells providing water to one or several sites. These independent supplies do not fall under the authority of OFWAT and are therefore called unregulated supplies. Finally, within an inset appointment one water company replaces another in a specific area. It is the most important of these new instruments; nevertheless, use of it has been made in only 18 cases so far (Cave, 2009, p.6). However, 40 demands for inset appointments are currently waiting for approval (Cave, 2009, p. 98). It is possible that the implementation of these measures will amplify in the future since the Government recently signaled its willingness to further increase competition in the water retail market - in line with the underlying wish to achieve a completely competitive retail market in the future, with customers freely choosing their provider, alike the electricity sector. Nevertheless, the movement into a real competitive water market is slow and loaded with barriers as two recent reports show (Cave 2008, 2009).

To sum up, the need to guarantee the alignment of the new mode of organization to the monopolistic properties of water systems and the institutional design in which it is embedded, with the key role of the Parliament and of the central regulator as its 'arm', has ended into a complex arrangement in the UK case. Difficulties encountered in the implementation of a truly competitive environment, and the tight and finicky regulation that frame the entire urban water system command a moderate appraisal of the liberalization implemented through the UK privatization model.

\section{III.2: France: More competitive pressure in PPPs, but limited risk-taking ${ }^{19}$.}

The French way towards liberalization is different. It is rooted in a long tradition of Public-Private Partnerships. The first delegation contract in the French water system goes back to 1856. However, PPPs have not always been as widespread as they are now, due to recent legal changes designed to favor a more open,

\footnotetext{
${ }^{19}$ If not otherwise mentioned, the numerical data is from Euromarket 2004a.
} 
competitive sector ${ }^{20}$. The main drivers behind the French liberalization movement are financial constraints, as in the UK, with ideological forces playing a much more subdued role. However, and this differs from the UK, it never reached the point of full privatization; and it was accompanied by a movement towards decentralization.

A turning point in that respect are two laws of decentralization passed in 1982, initiating a radical movement of transfer of competences from the central government to regional, departmental and municipal levels. Following these laws, the population supplied with water services under public management dropped from $50 \%$ to $25 \%$ within a few years.

The movement towards opening water systems to competition for the market was also fed by two other factors. Most French political leaders shared the widespread view conveyed by the worldwide push towards liberalization that PPPs would enhance efficiency. A snowball effect thus developed: impregnated with the new power associated to their extended responsibilities and simultaneously constrained by increasingly tight budgets, local public authorities succumbed to imitation. They found in widely publicized successful PPPs a source of inspiration for reforming their own water services, with the promise of efficiency gains and an alleviated financial burden. Another law adopted in 1999 (the so-called "Chevènement law"), on inter-municipal cooperation, strengthened this trend by encouraging administrative unitization among small and medium size communities. Nowadays, only $21 \%$ of the population get their water through public management (Aubin \& Varone, 2007, p.47). Hence, $79 \%$ of the population are provided by one of the three major French water operators: Veolia, Suez-Lyonnaise des Eaux, and SAUR. This means that, while liberalization accompanied decentralization in France whereas it went side by side with administrative centralization in the UK, liberalization produced similar effects when it comes to the organization of the industry: it favored big operators. This trend towards concentration was amplified by the increasingly demanding EU standards for drinking water and wastewater treatment. Being absurdly small sized, most French municipalities lacked the necessary know-how to comply with the tougher regulation and had to turn towards the expertise of the leading firms (Pezon, 2008).

\footnotetext{
${ }^{20}$ The movement is still going on. A new law was adopted on July 28, 2008, to facilitate Public-Private Partnerships in the provision of public infrastructures and services.
} 
However, liberalization remains limited. First, as almost everywhere in water systems, there is no competition in the market, while competition for the market attracts at best two or three competitors (most of the time from the big three). Moreover, $88 \%$ of delegation agreements in the sector are lease contracts (affermage in French), which means that the responsibility to invest (and the associated risks) stays with the municipality while the operator maintains and operates the network and manages the services. In almost all cases, the private operator collects water bills, takes a share contractually agreed upon, and transfers the remaining part to the municipality for re-investments in the system.

Hence, unlike the British model, risks are not fully shouldered by the private operator but shared, so that there is a significant gap between property rights and decision rights. Another difference is that the system is monitored through contractual agreements, not through an independent regulator. However, contracts are tightly bounded. It was already so for PPPs before the push towards liberalization. In the 1990s, the eruption of corruption scandals linked to bribery for obtaining delegation contracts and other irregularities put the model under pressure (Domanski, 2006). In order to better monitor the contractual regime, partly through intensified competition for the market, new laws were introduced. The so-called "Sapin Act" from 1993 intended to prevent corruption and to increase transparency, among other measures by making public tendering compulsory. Not long after, the so-called "Barnier Act" (1995) specified the rules for PPPs, clarifying conditions of entry, restricting contract duration, and forcing public authorities to publish annual reports on performance. It was rapidly followed by another law, the "Mazeaud Act", also from 1995, reducing the possibilities to extend contracts and obliging private operators to deliver annual reports to the delegating authorities.

How much these measures have enhanced competition in the French water sector is debatable. In a 1997 report, the French National Audit Office already highlighted the large number of exceptions to these laws, particularly with respect to the duration ${ }^{21}$, and the problems resulting from a highly oligopolistic market structure, with three players leading the ball. Moreover, the propensity to keep risks in the hands of public authorities might facilitate private participation, but it also severely

\footnotetext{
${ }^{21}$ There is a possibility to extend contracts if initially unplanned investments have been made by an operator.
} 
restricts responsibilities for private operators. Whether liberalization has favored competition therefore remains an issue.

\section{III.3: Germany: Corporatization as a step towards liberalization ${ }^{22}$ ?}

Of our three liberalization models for the water sector, the German one is clearly the less striking. Among the many factors that may explain this situation, a leading one might be embedded in the very nature of German political institutions. Germany is a federal state. Since each of the 16 states (Länder) has its specific law, the water sector is extremely fragmented, with thousands of small, local operators and many different modes of organization.

Consequently, no big operators dominate the national market, contrarily to the French or British situation. Only about $30 \%$ of the German population obtain their water under arrangements involving private sector participation, and this represents only about $9 \%$ of the total number of operating entities. The private sector is mostly active in big cities and in the eastern part of Germany (where, after the reunification, deteriorated water networks required heavy investments at a time of tight constraints on public finance).

In fact, PPPs remain the exception. Most of the water services are run under public management. Strong resistance towards liberalization developed in Germany, not only due to opposition by unions, but also because of persistent reluctance among the population to see water "privatized". A recent public opinion poll shows that $84 \%$ of the Germans are against further private sector involvement in the supply of stately provided services ${ }^{23}$. And regularly, when German municipalities' citizens are given the possibility to decide in a referendum, there are very strong reactions against private sector involvement in local public utilities. Illustrations are provided by the case of Münster, a city of 270,000 in the west of Germany, whose citizens voted "no" on the privatization of the municipal multi-utility ${ }^{24}$ in 2001 with a 2/3 majority and, more recently, by the case of Leipzig, a city of 511,000 in the east of Germany, where $87 \%$ of votes were against a partial sale of $49.9 \%$ of the stock to Gaz de France.

\footnotetext{
${ }^{22}$ For an analysis of the German water sector see Euromarket (2004a): Case Study Germany and Domanski (2006).

${ }^{23}$ Public opinion poll undertaken by Forsa, January 2008.

${ }^{24}$ In Germany, multi-utilities are a very common way of providing local public services like water, gas, and electricity through one provider, the Stadtwerke.
} 
However, pressures to "liberalize" the system have had an impact. Germany is moving away from the traditional Regiebetriebe, that is, from direct public management with water services run within municipal departments and financed by the general municipal budget. Severely criticized by the EU and the OECD (Palaniappan, Cooley, Gleick \& Wolff, 2006, p. 12 f.), among others, as lacking transparency and being opaque, the old form of direct public management is progressively leaving way to "corporatization".

Due to the federal structure of Germany and its extremely fragmented water sector, it is difficult to find consistent data concerning the different modes of organization. However, a study of the German Association of Energy and Water Industries (BGW, 2005, pp. $14 \mathrm{ff}$.) indicates an interesting development. The data on the water utilities show clearly that the German water sector has known a process of corporatization from 1986 to $2003^{25}$. Whereas direct public management under the form of Eigenbetriebe accounted for $63.3 \%$ of the water volume in 1986, it was only $14.9 \%$ in 2003 (and even only $4 \%$ in 2005). During the same period, corporatized utilities have grown from $12.7 \%$ to $30.2 \%$.

The main reason for this liberalization movement through corporatization lies in the growing financial pressure on municipal budgets. Municipalities hope to gain from corporatization in two ways. Firstly, once the utility is corporatized, it is more difficult for users to point the finger at the city council and blame the municipal administration for a service that is not perceived as functioning properly. Secondly, there is the hope to benefit from efficiency gains that can be realized within a more disciplining mode of organization which also leaves room for more powerful incentives.

\section{SECTION IV: SOME RESULTS AND TRENDS: COMFORTING, PUZZLING, OR DISTURBING?}

The three cases of England \& Wales, France and Germany illustrate well the many different forms that the introduction of market pressures can take in the water sector. A key argument behind the liberalization movement is that the introduction of

\footnotetext{
${ }^{25}$ This trend is further confirmed by a more recent study (BGW 2008, p. 14).
} 
private interest or at least the very possibility of private sector participation would enhance performance ${ }^{26}$. However, this remains much debated in empirical works.

\section{IV.1: Mixed impact of changes in the allocation of property and decision rights.}

At the empirical level, several studies on the effect of the reallocation of ownership on efficiency exhibit ambiguous results in the water sector. Studies from Ménard and Saussier (2002), Pérard (2007); Gassner et al. (2007, 2009); Wallsten and Kosec (2008), among others, suggest that ownership may not be the key issue, which does not mean that it can be ignored. At the same time, Cave $(2008 ; 2009)$ and a recent report from the World Bank (2009) emphasize the advantages of private participation, although not necessarily full privatization in the case of the World Bank. And a challenging fact is that major operators at the international level do not lobby that much in favour of full privatization.

Whereas the standard economic theory predicts inefficient public ownership, case based evidence raises questions about such a general statement. Pérard (2007, p. 31) suggests that public water services can be managed very efficiently when the institutional setting is right, as he illustrates in the case of Tunisia, with efficient water services provided by two centralized agencies monitored by the government ${ }^{27}$. In this country, water is reasonably priced and represents $0.65 \%$ of the per capita income per month ${ }^{28}$. At the same time, an unaccounted-for-water (UFW) of $18 \%$ keeps up with the $19.2 \%$ of the completely privatized water services of England and Wales and is even better when compared to the $26.4 \%$ of the French PPPs (BGW, 2005, p. 24).

Wallsten and Kosec (2006) confirm the view that ownership alone does not explain the performance of water utilities. It is rather the competitive pressure that makes the difference: benchmarking leads to a better performance. This might be compatible with public ownership, if benchmarking is implemented. Our three liberalization models may well substantiate this argument. The German water sector, with thousands of small, (mainly) public entities that allow citizens/consumers to compare price and quality, outperforms the two other models. According to the BGW

\footnotetext{
${ }^{26}$ This is tying up to the considerations about contestable markets, where the simple threat of some other company chasing away the incumbent is sufficient to improve the latter's performance.

${ }^{27}$ See also Touzi (2009). A similar conclusion can be derived from the case study on Santiago-de-Chile in Shirley (2002, chap.6).

${ }_{28}$ Own calculations based on Baietti, Kingdom \& van Ginneken, 2006, p. 5 and SONEDE (http://www.sonede.com.tu/fra/E_SC.html (12.01.2009).
} 
study (2005, p. 24), which looked at several key indicators, water loss is at a high in France, with 26.4\% UFW , followed by England \& Wales (19.2\%), while Germany exhibits a low $7.3 \%$ of UFW ${ }^{29}$. Consistently, investments per cubic meter of water are highest in Germany $(0.55 €)$, followed by England \& Wales $(0.47 €)$, with France significantly behind $(0.37 €)$. Last, the per capita water bill per year for a standardized water consumption accounts for $100 €$ in England \& Wales and $85 €$ in France, while it accounts for $82 €$ in Germany.

Of course, these indicators are very incomplete and do not provide clear-cut "proofs" of the performance of the alternative models for liberalization. However they converge with some other troubling factors.

When it comes to full privatization, one could point out flaws in the institutional design of innovative solutions. For example, in the English \& Welsh case, the regulator (OFWAT) plays a major role with respect to the performance of the sector. Changes in its mission over time have generated uncertainties. While its initial role was to facilitate competition, it has progressively shifted towards actively promoting it, leading to tighter price caps over recent years. As a result, tariffs for water services in England \& Wales are quite low. But at the same time this pressure on the operators leads to under-investments and the prospect of deterioration of the networks in the medium term. Furthermore, OFWAT's credibility has been undermined when the regulator did not enforce the fines it imposed on some operators. Moreover, new instruments have not proven to significantly improve competition. If this will change in the future, due to recent developments, such as the promised movement towards some retail competition, needs to be awaited (Cave, 2009, p. 77).

If we now turn to the second model of liberalization, PPPs, we are immediately confronted to standard problems of tariff increases, under-investment, especially towards the ending period of contracts, risk-averse strategies of operators so that public authorities tend to bear most of the uncertainties, and the very high rate of renegotiations, all of which questions the presumed efficiency of this mode of organization. In his extensive study of PPPs in Latin America, Guasch (2004)

\footnotetext{
${ }^{29}$ These numbers are consistent with data provided by the French Environment Institute (IFEN) and the economic regulator for the English and Welsh water sector (OFWAT), see http://www.ifen.fr/donneesessentielles/eau/gestion-de-1-eau-potable-et-des-eaux-usees/la-distribution-de-l-eau-potable.html?taille $=\quad$ and http://www.ifen.fr/actualites/presse/detail-d-un-communique-ou-dossier/article/eaupotable.html?tx ttnews[backPid]=879\&cHash=012221ae42 for the French case and http://themes.eea.europa.eu/Specific_media/water/indicators/WQ06,2003.1001 for England \& Wales (accessed 3 June 2009).
} 
showed that $74.4 \%$ of water contracts were renegotiated, on average only after 1.6 years! From a transaction cost perspective, these frequent renegotiations are very costly: directly, because they bind the parties in a process that takes 3 to 12 months, mobilising experts, lawyers and so forth; but also indirectly since they undermine the credibility of the operators, the public authority, and ultimately the supporting institutions. More recently, Gassner et al. (2009) concluded their review of the private sector participation in electricity and water distribution with some scepticism about the overall impact of PPPs

Last, if we turn to corporatization, it also confronts problems, particularly because of political interferences on tariffs and employment. A major issue with respect to the performance of public corporations concerns overstaffing, as well illustrated by the German case of Munich. The ratio of employees per 1000 connections of the city's utility provider amounts to 19.5 albeit a ratio of 4 or 5 is usually considered enough to deliver satisfactory performance.

\section{IV.2: Expectations: Showdown... or slowdown?}

Taking these difficulties into account, what future can be expected for liberalization in the water sector, and particularly for private sector participation?

First of all, we have to keep in mind that the implication of the private sector in water services remains low. It represents only $11 \%$ of the provision of drinkable water worldwide, although the percentage is higher in urban areas (25\%), since operators can take advantage of density effects, particularly in urban areas of developed countries (33\%). Moreover, the push towards PPPs, especially in developing countries has been quite bumpy (Pérard, 2007; Gassner et al., 2007) ${ }^{30}$. Nevertheless, PPPs are still viewed as an important option for developing countries since they should allow access to capital and the necessary expertise. At the same time, data suggest that private operators are increasingly reluctant to assume risks of significant investments, which finds an expression in the growing role of management and lease contracts (Palaniappan et al., 2006), in which the main risks remain with the public party. In many cases, the trend is rather towards corporatization, with the end of mega-concessions (Saghir, 2006).

\footnotetext{
${ }^{30}$ For detailed data on the evolution of PPPs, see the World Bank Private Participation Infrastructures database at: http://ppi.worldbank.org/explore/ppi_exploreSector.aspx?sectorID=4 (accessed 7 April 2011)
} 
This revision of the initial optimism might very well affect developed countries as well. In the European Union, the Commission has passed a procurement directive intending to favour the delegation of public services and to intensify competitive pressures. However, the same authority has imposed tougher regulation as well as full cost recovery for externalities, thus introducing elements of uncertainty that might make private operators reluctant to assume too many risks in long run investments ${ }^{31}$.

This may partly explain some significant evolutions regarding the liberalization of the water sector in the $\mathrm{EU}^{32}$. First, the English model of complete divestiture remains unique and has not been imitated.

Second, private sector participation seems to have been increasingly associated with the role of large groups, feeding an oligopolistic structure. Even within the English model, there has been a significant movement towards vertically integrated companies. As a result, the English Authorities have amended the Water Industry Act from 1991 with the Enterprise Act (2002), which imposes tighter monitoring of future merger and acquisition projects ${ }^{33}$. Nevertheless, the trend towards integration remains powerful everywhere, including among public corporations. Pezon (2008) highlights the increasing role of supra-communal authorities integrating several water and sewerage services in France, particularly in rural areas ${ }^{34}$.

Third, several water companies facing increased financial pressures have proposed arrangements in which networks would be run by private non-profit organizations that would "delegate" the service provision to for-profit companies (Euromarket, 2004a). Liberalization would then involve switching from Public Private Participation to Private-Private Participation, with a quasi-public entity assuming almost all risks.

Hence, liberalization in the water sector is no longer identified with full privatization and is even less identified than before with substantial private sector participation. In France, private operators remain welcome, particularly in areas with a low population density since public authorities are faced with heavy investments required by tougher regulations that they can hardly face. Unfortunately these are also areas less attractive for private operators. Simultaneously, there are signs of

\footnotetext{
${ }^{31}$ See European Commission (2008).

${ }^{32}$ For an overview of a similar trend in the US, see Warner (2007).

${ }^{33}$ However, as a reaction to the Cave report from 2008, the Government considers reviewing the current merger regime, which has been criticized as being too rigid (Cave, 2009, p. 77).

34 The trend towards integration in the sector has also been noticed in developing countries (see Pérard, 2006).
} 
pressure towards re-municipalization in larger and more profitable cities (Grenoble, already in the 1990s, and now Paris, and possibly other major cities) ${ }^{35}$. In Germany, the Federal Agency for Hydrology has explicitly opposed the liberalization movement (Bundesanstalt für Gewässerkunde, 2002, p. 28), arguing that under the existing publicly monitored regime the quality of drinking water is exceptionally high in international comparison, with a highly secure supply. However, the need to improve the efficiency of the system has been acknowledged, and a working group has defined a modernization strategy that would rely on benchmarking (including among corporatized utilities) as well as on economies of scale and scope through integration of water and sewerage services, a sensitive issue in Germany because of the diversity of fiscal rules among municipalities and Länder as well as between these two sectors.

All in all, there seems to be an agreement that the trend towards more concentration is widespread in Europe (Euromarket, 2004b). An issue then becomes whether this will favor a handful of very large companies, be they private or public, thus creating a very oligopolistic market structure at the European level.

\section{CONCLUSION.}

In this chapter, we have developed two main points. First, we have argued that "liberalization" is a relatively vague concept, providing an umbrella for many different types of reform. For a time, it has been identified to privatization. However, full privatization in the drinkable water sector, on which we focused here, remains a very exceptional case so far. If we relax the concept of liberalization in order to focus on the idea that it corresponds to the introduction of competitive pressures, then there has been unambiguously a powerful movement towards liberalization in the water sector, with the prevalence of two main models that are distinct from full privatization: PPPs, which take different forms of contractual arrangements that basically introduce more or less intense 'competition for the market'; and "corporatization", that is, the transformation of services providing water into legally and economically autonomous entities accountable for their performance very much like a private firm would be, so that benchmarking becomes possible.

\footnotetext{
${ }^{35}$ A similar trend for water and other utilities might also be on its way in the US (see Warner, 2007).
} 
Second, referring to three "stylized" examples from Europe, with comparable and converging environments in terms of standards of living, consumption of water, technologies in use, etc., we have exhibited mixed results for the three "models" under review. One reason for this state of affair is that modes of organization for providing water evolve slowly and are deeply embedded in specific institutions that combine national traditions, as with the French PPPs, and micro-institutions, as with the German local water utilities. But even more importantly, we have argued that there are specific characteristics of the water sector that may well explain resistance to liberalization, perceived as a transfer of property rights and/or of decision rights that would deprive citizens from their control over a non standard good. These specific characteristics affect both the supply side, since water provision obeys conditions that are very close to that of a pure natural monopoly, and the demand side, since water is so crucial for human survival and therefore so politically sensitive.

As a result, drinking water provision is a highly exposed activity, that can hardly escape opportunistic pressures that take many different forms: political opportunism from public authorities, opportunistic behavior from operators (whether they are private or public), and third party opportunism from interest groups (including consumer associations). Consequently, liberalization in the water sector is a mode of reform that has a dense and omnipresent institutional dimension. It is at risk of generating high economic and political transaction costs, thus creating uncertainties or even having dramatic consequences that feed suspicion regarding liberalization. Shirley and Ménard (2002) argued that this might contribute to explain the slow pace of reforms in the water sector, and the dramatic events it often requires before these reforms are initiated. It is most of the time only when major macro tensions, such as very tight financial constraints, combine with sector crisis, as when drinkable water does not reach significant segments of the population, that restructuring water systems comes high on political agendas.

Ultimately, for all these reasons, one can predict with a quite high probability that liberalization in drinking water systems and the introduction of competitive pressures will remain on the agenda and, at the same time, with limited effects. One may even suspect that with the increasing scarcity of the resource and the growing conflicts of interest among its users, public control will increase rather than decrease. We are entering in a world in which strategic control over water becomes also a geostrategic issue. 


\section{REFERENCES}

Aubin, D., F. Varone (2007), "Policies Regulating the Water Supply and Sanitation Sector in Nine European Countries", in: Finger et al. (eds.) (2007), chap. 2, pp. 3453.

Baietti, A., W. Kingdom, M. van Ginneken (2006), "Characteristics of Well-Performing Public Water Utilities", Water Supply and Sanitation Notes, note number 9, may 2006, World Bank.

Baumol, W. J., Panzar, J., Willig, R. D. (1982), "Contestable Markets and the Theory of Industry Structure", San Diego, CA: Harcourt Brace Jovanovich.

Bonnet, C., P. Dubois, D. Martimort, S. Straub (2006), "Empirical Evidence on Satisfaction with Privatization in Latin America: Welfare Effects and Beliefs", Working Paper, IDEI, Toulouse, October.

Bundesanstalt für Gewässerkunde (BfG) (2002), Water Resources Management Country Profile Germany, Report 27, Koblenz: BfG.

Bundesverband der deutschen Energie- und Wasserwirtschaft (BGW) (2008), "Branchenbild der deutschen Wasserwirtschaft 2008".

Bundesverband der deutschen Gas- und Wasserwirtschaft (BGW) (2005), "Branchenbild der deutschen Wasserwirtschaft 2005".

Cave, M. (2008), Cave Review of Competition and Innovation in Water Markets. Preliminary Report. http://www.defra.gov.uk/environment/water/industry/cavereview , (02/23/2009).

Cave, M. (2009) Cave Review of Competition and Innovation in Water Markets. Final Report. http://www.defra.gov.uk/environment/water/industry/cavereview, (06/03/2009).

Domanski, A. (2006), Corruption et Services Publics - Le Cas du Secteur de l'Eau, Master Thesis, Paris: Université de Paris (Panthéon - Sorbonne).

Esrey (1996) "Water, Waste and Well-being: A Multi-country Study". American Journal of Epidemiology, 143: 608-623.

Euromarket (2004a), "Work Package 4: Analysis of the Legislation and Emerging Regulation at the EU Country Level", in: Research Project on Water liberalisation scenarios: An empirical analysis of the evolution of the European water supply and sanitation sectors, Community Research Project by the European Commission, http://mir.epfl.ch/webdav/site/mir/shared/import/migration/EUROMARKET D4 Final Report.pdf , (06/03/2009).

Euromarket (2004b), "Work Package 3: Analysis of the Strategy of the Water Supply 
and Sanitation Operators", in: Research Project on Water liberalisation scenarios: An empirical analysis of the evolution of the European water supply and sanitation sectors, Community Research Project by the European Commission, http://mir.epfl.ch/webdav/site/mir/shared/import/migration/D3\%20\%20Work\%20Package\%203\%20final\%20version\%20July\%202004 1.pdf , (06/03/2009).

European Commission (2008), "Economics in Water Policy: The Value of Europe's Water", Water Information System for Europe - Water Note on the Implementation of the Water Framework Directive 5, Brussels: European Commission.

Finger, M., J. Allouche, P. Luis-Manso (eds.) (2007), Water and Liberalization. European Water Scenarios, London: IWA Publishing.

Garcia, S., L. Guerin-Schneider, L. Breuil ( 2007), "Analysis of the European Union Explicit and Implicit Policies and Approaches in the Water Supply and Sanitation Sectors", in: Finger et al. (eds.) (2007), chap. 3, pp. 54-81.

Gassner, K., A. Popov, N. Pushak (2007), An Empirical Assessment of Private Sector Participation in Electricity and Water Distribution in Developing and Transition Countries, Working Paper, Washington D. C.: World Bank, http://siteresources.worldbank.org/INTSDNETWORK/Resources/2007 June Impact of PSP in elec and water.pdf, (accessed 3 June 2009).

Gassner, K., A. Popov, N. Pushak (2009), "Does Private Sector Participation Improve Performance in Electricity and Water Distribution?", Trends and Policy Options, 6, Washington D. C.: World Bank.

Guasch, J. L. (2004), Renegotiating Infrastructure Concessions: Doing It Right, Washington D.C.: World Bank.

Hall, D., E. Lobina (2007), "International Actors and Multinational Water Company Strategies in Europe, 1990-2003", Utilities Policy, 15, pp. 64-77.

Kunneke, R. W., J. Groenewegen, C. Ménard (2009), "Aligning Institutions with Technology: Critical Transactions in the Reform of Infrastructures", Working Paper.

Lanz, K. (2005), Case study - Munich, Germany, Watertime, Research project financed by the European Commission, http://www.watertime.net/docs/WP2/D34 Munich.doc (accessed 3 June 2009).

Massarutto, A., E. Linares, V. Paccagnan (2007), "Liberalisation and Private Sector Involvement in WSS: The European Experience", in: Finger et al. (eds.) (2007), chap. 9, pp. 196-216.

Ménard C., M. Ghertman (eds) (2009), Regulation, Deregulation, Reregulation. Institutional Perspectives. Cheltenham: E. Elgar.

Ménard, C. (2009), "From Technical Integrity to Institutional Coherence: Regulatory Challenges in the Water Sector", in: Ménard, C., M. Ghertman (eds.), pp. 83-108. 
Ménard, C., S. Saussier (2002), "Contractual Choice and Performance", in: Brousseau, E. and J-M. Glachant (eds.), pp. 440-462.

Palaniappan, M., H. Cooley, P. Gleick, G. Wolff (2006), "Assessing the Long-Term Outlook for Current Business Models in the Construction and Provision of Water Infrastructure and Services", paper for the Global Forum on Sustainable Development, Paris: OECD, November.

Pérard, E. (2007), Private Sector Participation and Regulatory Reform in Water Supply: The Southern Mediterranean Experience, Development Centre Working Papers, Paris: OECD.

Pezon, Ch. (2008), Intercommunalité et Durabilité des Services d'Eau Potable et d'Assainissement, Rapport, Ministère de l'Environnement et du Développement Durable (MEDD).

Pinsent Masons (2004), Water Yearbook 2004-2005, London: Pinsent Masons.

Pinsent Masons (2008), Water Yearbook 2008-2009, London: Pinsent Masons.

Saghir, J. (2006), "Public-Private Partnerships in Water Supply and Sanitation Recent Trends and New Opportunities", presentation for the Global Forum on Sustainable Development, November 2006, Paris: OECD.

Savedoff, W., P. Spiller (1999), Spilled Water - Institutional Commitment in the Provision of Water Services, Washington D. C.: Inter-American Development Bank.

Schouten, M., M.P. van Dijk, (2007) "The European Water Supply and Sanitation Markets", in: Finger et al. (eds.) (2007), chap. 1, pp. 11-33.

Shirley, M. M. (ed.) (2002), Thirsting for Efficiency - The Economics and Politics of Urban Water System Reform, Amsterdam and others: World Bank.

Shirley, M. M., C. Ménard (2002), "Cities Awash: A Synthesis of the Country Cases", in: Shirley, M. M. (ed.) (2002), pp. 1-41.

Wallsten, S., K. Kosec (2008), "The Effects of Ownership and Benchmark Competition: An Empirical Analysis of U.S. Water Systems", International Journal of Industrial Organization, 26 (2008), pp. 186-205.

Warner, M. And A. Hefetz (2007) "Beyond the" market versus planning dichotomy: understanding privatization and its reverse in US cities", Local Government Studies, 33 (4), 555-572

World Bank (1994), World Development Report 1994: Infrastructure for Development, World Bank / Oxford University Press.

World Bank (2009), 2008 Annual Report, Washington D.C.: World Bank. 